\title{
Potentiation of acetylcholine action in the ventral tegmental area facilitates morphine-state dependent learning Niloufar Darbandi*1, Ameneh Rezayof ${ }^{1}$ and Mohammad-Reza Zarrindast ${ }^{2}$
}

\author{
Address: ${ }^{1}$ Department of Animal Biology, School of Biology, College of Science, University of Tehran, Tehran, Iran and ${ }^{2}$ Department of \\ Pharmacology, School of medicine, Tehran University of Medical Sciences, Tehran, Iran \\ * Corresponding author
}

\author{
from International Society on Brain and Behaviour: 3rd International Congress on Brain and Behaviour \\ Thessaloniki, Greece. 28 November - 2 December 2007 \\ Published: 17 April 2008 \\ Annals of General Psychiatry 2008, 7(Suppl I):S200 doi:I0.II86/I744-859X-7-SI-S200
}

This abstract is available from: http://www.annals-general-psychiatry.com/content/7/SI/S200

(C) 2008 Darbandi et al.; licensee BioMed Central Ltd.

\section{Background}

It is well known that morphine influence learning and memory processes. the ventral tegmental area (VTA) which has an important role in reward, participates in morphine-induced impairment of memory retention [1]. Considering the cholinergic system is involved in the effects of morphine on memory [2], in the present study, the effects of intra-VTA injections of an anticholinesterase, physostigmine on morphine-state dependent learning has been investigated in rats.

\section{Materials and methods}

A single-trial step-through passive avoidance task was used for the assessment of memory retention in male Wistar rats. Animals were bilaterally cannulated in the ventral tegmental area by stereotaxic instrument, and were allowed to recover 1-week before behavioral testing.

\section{Results}

Post-training subcutaneous (s.c.) administration of different doses of morphine dose dependently decreased the learning and induced amnesia. The administration of the same dose of morphine as pre-test treatment induced state-dependent learning. Pre-test intra-VTA injection of physostigmine with an ineffective dose of morphine significantly restored the retrieval and potentiated morphine state-dependent memory. Moreover, Pre-test intra-VTA administration of the physostigmine alone did not affect memory retention.

\section{Conclusions}

This findings indicate that the potentiation of cholinergic system in the VTA by physostigmine facilitates morphine state-dependent learning.

\section{References}

I. Zarrindast MR, Farajzadeh Z, Rostami P, Rezayof A, Nourjah P: Involvement of the ventral tegmental area (VTA) in morphine-induced memory retention in morphine-sensitized rats. Behavioural Brain Research 2005, 163:100-106.

2. Jafari MR, Zarrindast MR, Djahanguiri B: Influence of cholinergic system modulators on morphine state-dependent memory of passive avoidance in mice. Physiology \& Behavior 2006, 88: $|46-15|$. 